Instructions for authors, subscriptions and further details:

http://ijep.hipatiapress.com

\title{
Teacher Education for High Poverty Schools
}

Icy Fresno Anabo ${ }^{1}$

1) Deusto University, Spain.

Date of publication: October $24^{\text {th }}, 2016$

Edition period: October 2016 - February 2017

To cite this article: Anabo, I. F. (2016). [Book Review of Teacher Education for High Poverty Schools by J. Lampert and B. Burnett ] International Journal of Educational Psychology, 5(1), 336-338. doi: 10.17583/ijep.2016.2280

To link this article: http://dx.doi.org/10.17583/ijep.2016.2280

\section{PLEASE SCROLL DOWN FOR ARTICLE}

The terms and conditions of use are related to the Open Journal System and to Creative Commons Attribution License (CC-BY). 


\section{Review}

Lampert, J., and Burnett, B. (Eds). (2016). Teacher education for high poverty schools. New York: Springer International Publishing.

Reducing poverty and inequality of opportunities has been increasingly at the forefront of political agendas in the global landscape, with education being put forward as an indispensable means to resolve these social issues. One of the important aspects of responding to the pressing concern of poverty and its consequences is the availability of, and access to, quality and well-prepared teachers.

The book "Teacher Education for High Poverty Schools" edited by Jo Lampert and Bruce Burnett is a compilation of recent researches, management approaches, and pedagogical advances in the realm of teacher education and recruitment for high-poverty educational settings in six country contexts - the US, Canada, Australia, Chile, South Africa, and the UK. It offers sufficient introductory coverage into the theories, practices, and tensions involved in educating quality teachers for disadvantaged populations through the lenses of social justice and critical pedagogy.

A relevant task tackled in the book is exposing the many faces of disadvantage. As exemplified in the book's chapters, being poor can mean more than just having a low socio-economic status: it can also be conflated with other forms of disadvantage as experienced by students in urban settings, suburban schools, and areas with high linguistic diversity and cultural dissonance between staff and students. Poverty, as framed in dominant discourse and as has been shown in numerous studies, is problematic because it plays a role in below-par educational performance and poor student outcomes. 


\section{Anabo - Teacher Education for High Poverty Schools [Book Review]}

The book balances this commonsensical interpretation of the nature of the educational achievement gap in school outcomes with the deconstructive aspect of poverty by inviting its readers to adopt a critical and reflective approach. It is argued that automatically linking poverty with academic underperformance and intellectual inferiority is a form of epistemic injustice (Fricker, 2007) that disregards the rich resources present in the students' experiences themselves. It contends that moving forward in teacher education entails engagement in the practice of deconstructing the existing measures and our very own attitudes and assumptions about poverty as well as our deep-seated biases against students who are "poor," "urban," or "indigenous." The authors propose a paradigm shift away from individual blame towards acknowledging that the system is fraught with inequities and homogenizing tendencies. By breaking away from deficit thinking to an asset-based frame of reference, teachers and teacher educators can also respond more effectively to the reality and the concomitant challenges of increasingly diverse student populations.

Alongside providing ample literature to reference its social justice and critical pedagogy roots, the book sets forth to illustrate practical approaches to governance, curriculum design, and classroom practice. At the macro level, it describes some efforts to redistribute not just well-meaning but also academically competent teachers to areas that need them the most through projects like the National Exceptional Teachers for Disadvantaged Schools in Australia (Chapter 4) and Teach First in England (Chapter 8). At the meso-level, institutions and teacher education curriculum developers will benefit from the examples given on how to approach teacher recruitment and retention in high poverty settings, how to incorporate family and community involvement into the curricula for pre-service teachers, and how to facilitate critical inquiry and teacher-researcher roles among pre-service teachers through pedagogical tools. The book also provides practicing teachers some insights on how to leverage diversity in the classroom and to enact an assetbased frame of reference in planning lessons and activities.

Indeed, the strength of the book lies in its ability to cater to various actors -policy makers, families and communities, school leaders, and teacherresearchers -- involved in high poverty educational settings. Its holistic and 
multi-level approach to the issue is a sober attempt to locate the features of responsive teacher education programs in the complex web of structural and dispositional limitations. The book also advertently warns against romanticizing the role of teacher education in addressing poverty, which reaffirms the fact that teachers cannot and should not be expected to generate change single-handedly.

Although admittedly non-exhaustive, the book is a good departure point to get a good grasp of teacher education with a social justice perspective. Even readers without a robust knowledge of relevant theories will find it a useful material to reflect on and a valuable resource to inform their respective practices and contexts.

\section{References}

Fricker, M. (2007). Epistemic injustice: Power and the ethics of knowing. Oxford, UK: Oxford University Press

Icy Fresno Anabo

Deusto University icy.anabo@opendeusto.es 